Aspirasi: Jurnal Masalah-Masalah Sosial | Volume 9, No, 2 Desember 2018

ISSN: 2086-6305 (print) ISSN: 2614-5863 (electronic)

DOI: https://doi.org/10.22212/aspirasi.v7il.1084

link online: http:/jurnal.dpr.go.id/index.php/aspirasi/index

\title{
PERBEDAAN KESEJAHTERAAN SISWA PADA SISWA SMA NEGERI ASRAMA DAN BUKAN ASRAMA DI KOTA MALANG
}

\author{
School Well Being Differences between Students of Boarding High School \\ versus Day High School in Malang City
}

\author{
Sulis Winurini \\ sulis.winurini@dpr.go.id \\ Pusat Penelitian Badan Keahlian DPR RI \\ Jl. Gatot Subroto Senayan Jakarta
}

Naskah Diterima: 10 Oktober 2018 | Naskah direvisi: 4 Desember 2018 | Naskah diterbitkan: 31 Desember 2018

\begin{abstract}
Boarding schools have their own peculiarities. Students in boarding schools will spend all their time in schools and dormitories, while students in day schools still have experience with their families and neighborhoods. This difference in experience will lead to differing perception, so it is assumed that there are differences in school well being in the two school models. The purpose of this study is to find out whether or not there is a difference in school well being for students in boarding public high schools (SMAN) with day public high schools (SMAN) in Malang. Using quantitative method. The research was conducted in Malang City on July 19, 2018. The total participants involved in this study were 186 people, consisting of 89 students from day high schools and 97 students from boarding high school. The results of the study using the t-test showed a significant difference in the average score in the variable school well being between boarding high school students and day high school students $(t=5.29 ; p<0.05)$. The average score of a school well being at boarding school is higher than day school. Viewed from its aspect, it was found a significant difference in scores significantly on the aspect of having, not found a difference in the average score significantly on the love aspect, found the difference in average scores was significantly on the aspect of being. Judging from the average score of each aspect, the boarding high school students have an average score of the aspect of the school well being higher than the day high school students. That is, if viewed on a per-aspect basis of school well being, boarding high school students feel better than day high school students.
\end{abstract}

Keywords: school well being, boarding school, day school, public shool, high school student

\begin{abstract}
Abstrak: Sekolah asrama memiliki kekhasan tersendiri. Siswa yang berada di sekolah asrama akan menghabiskan seluruh waktunya di sekolah dan asrama, sementara siswa pada sekolah bukan asrama masih memiliki pengalaman dengan keluarga dan lingkungan tempat tinggalnya. Perbedaan pengalaman ini akan menimbulkan perbedaan penilaian sehingga diasumsikan terjadi perbedaan kesejahteraan siswa pada kedua model sekolah tersebut. Tujuan dari penelitian ini adalah untuk mengetahui ada atau tidaknya perbedaan kesejahteraan siswa yang berada di SMA Negeri (SMAN) asrama dengan SMA Negeri (SMAN) bukan asrama di Kota Malang. Penelitian ini menggunakan metode kuantitatif di Kota Malang pada tanggal 19 hingga 26 Juli 2018. Total partisipan yang digunakan dalam penelitian ini adalah 186 orang, terdiri dari 89 siswa dari SMAN bukan asrama dan 97 siswa dari SMAN asrama. Hasil penelitian dengan menggunakan t-test menunjukkan perbedaan rata-rata skor secara signifikan pada variabel kesejahteraan siswa di sekolah antara siswa SMAN asrama dengan siswa SMAN bukan asrama $(\mathrm{t}=5,29 ; \mathrm{p}<0,05)$.
\end{abstract}


Rata-rata skor kesejahteraan siswa di SMAN asrama lebih tinggi dibanding SMAN bukan asrama. Dilihat dari aspeknya, ditemukan perbedaan rata-rata skor secara signifikan pada aspek kondisi sekolah, tidak ditemukan perbedaan rata-rata skor secara signifikan pada aspek hubungan sosial, ditemukan perbedaan rata-rata skor secara signifikan pada aspek pemenuhan diri. Dilihat dari rata-rata skor tiap aspeknya, siswa SMAN asrama memiliki rata-rata skor aspek kesejahteraan siswa di sekolah lebih tinggi dibanding siswa SMAN bukan asrama. Artinya, jika dilihat secara per aspek kesejahteraan siswa di sekolah, siswa SMAN asrama merasa lebih baik dibanding siswa SMAN bukan asrama.

Kata kunci: kesejahteraan siswa di sekolah, sekolah asrama, sekolah nonasrama, sekolah negeri, siswa SMA

\section{Pendahuluan}

Sekolah merupakan salah satu pusat tersedianya berbagai pengalaman bagi seorang siswa. Sekolah menyediakan kesempatan bagi siswa untuk membentuk dan mengembangkan dirinya melalui pengalaman-pengalaman yang ia dapat di sekolah. Pengalaman siswa berhubungan dengan hal-hal yang terkandung di dalam sekolah, seperti: kondisi fisik sekolah, tugas, pelajaran, ujian, peraturan, teman-teman, guru, kepala sekolah, nilai-nilai yang diajarkan sekolah, termasuk perasaan siswa mengenai sekolahnya (Winurini, 2004). Pengalaman-pengalaman tersebut penting untuk diketahui karena apa yang dialami siswa di sekolah dapat menjadi sumber pembentukan diri, baik secara intelektual, sosial, dan emosional (Ryan dan Cooper, 1984).

Pengalaman siswa di sekolah berpengaruh terhadap kesejahteraan siswa pada sekolah tersebut, sebagaimana yang dibuktikan oleh Konu dan Rimpela (2002 dalam Kurniasih, 2017) yang mengindikasikan bahwa konteks sekolah berpengaruh terhadap kesejahteraan siswa di sekolah. Kesejahteraan siswa di sekolah bukan saja dipengaruhi oleh faktor-faktor dukungan sosial (orang tua, guru, dan teman), tapi juga oleh kondisi sekolah (kenyamanan, dampak positif, dan dampak negatif). Kesejahteraan siswa di sekolah dapat dilihat dari bagaimana sekolah memenuhi kebutuhan siswa, sebagaimana pendapat Konu dan Rimpela (2002 dalam Kurniasih, 2017) yang mendefinisikan kesejahteraan siswa di sekolah sebagai sebuah keadaan sekolah yang memungkinkan individu memuaskan kebutuhan dasarnya, meliputi: (1) kondisi sekolah; (2) hubungan sosial; (3) pemenuhan diri; dan (4) status kesehatan. Pada rumusan konsep kesejahteraan siswa di sekolah selanjutnya, aspek kesehatan dipisahkan dari aspek-aspek lainnya. Aspek kesejahteraan siswa di sekolah menjadi kondisi sekolah, hubungan sosial, dan pemenuhan diri (Konu dan Rimpela, 2002).

Kesejahteraan siswa di sekolah berkorelasi dengan peningkatan hasil akademik, kehadiran di sekolah, perilaku prososial, keamanan sekolah dan kesehatan mental (Noble, McGrath, Roffey \& Rowling, 2008). Apabila situasi sekolah sehat, maka siswa yang ada di sekolah tersebut akan memiliki sikap yang positif terhadap sekolah tersebut. Sikap yang positif akan menurunkan tingkat stres siswa dan pada akhirnya akan meningkatkan prestasi siswa di sekolah (Konu dan Rimpela, 2002). Siswa yang merasa tidak sejahtera dengan sekolahnya akan sering membolos (Leonard, Bourke dan Schofield, 2000). Sebuah studi menunjukkan bahwa kebanyakan siswa yang merasa puas dengan sekolahnya hanya memiliki sedikit perasaan negatif pada saat berada di sekolah, begitupun sebaliknya dengan siswa yang tidak merasa puas dengan sekolahnya. Sementara itu, kepuasan siswa terhadap sekolah berhubungan positif dengan penerimaan siswa terhadap nilai-nilai pendidikan, motivasi belajar, dan komitmen di dalam sekolah (Goodenow dan Grady, 1992; Wehlage, Rutter, Smith, Lesko dan Fernandez, 1989 dalam Sen Keung, 1999). Sebaliknya, ketidakpuasan siswa terhadap sekolah memiliki hubungan positif dengan prestasi belajar yang buruk dan perilaku yang bermasalah di sekolah (Baker, 1998 dalam Sen Keung, 1999). Beberapa hasil penelitian ini menunjukkan bahwa 
kesejahteraan siswa di sekolah penting bagi kesejahteraannya secara keseluruhan.

Oleh karena itu, menjamin kesejahteraan siswa harus menjadi misi dan peran utama sekolah. Salah satu model sekolah yang saat ini sedang berkembang adalah sekolah asrama. Banyak orang tua menitipkan anaknya ke sekolah asrama karena merasa tidak memiliki banyak waktu untuk memantau anak-anaknya dalam kegiatan keseharian. Mereka memilih sekolah asrama dengan harapan anak-anak mereka mendapatkan pengawasan yang lebih intensif. Lingkungan kehidupan remaja yang negatif, seperti: pergaulan bebas, penggunaan narkoba, keikutsertaan dalam aksi tawuran, dan lainnya, ikut mendorong orang tua menyekolahkan anaknya di sekolah asrama (Maslani dalam Kurniasih dan Lestari, 2017).

Sekolah asrama adalah model sekolah yang mewajibkan siswanya untuk menginap selama bersekolah di sekolah tersebut atau dengan waktu yang ditentukan sekolah tersebut (Dimyati dalam Kurniasih dan Lestari, 2017). Siswa yang berada di sekolah asrama akan menghabiskan seluruh waktunya di sekolah dan asrama sehingga pengalamannya penuh dengan hal-hal tentang sekolah dan asrama. Kurniasih dan Lestari (2017) pernah melakukan penelitian tentang kesejahteraan siswa di sekolah asrama. Hasil penelitian menunjukkan bahwa siswa di sekolah asrama pada awalnya mengalami kesejahteraan yang rendah karena belum bisa beradaptasi dengan lingkungan asrama, di samping ada banyak kasus perundungan. Seiring berjalannya waktu, siswa dapat beradaptasi, bisa lebih akrab dengan teman, lebih dekat dengan guru pendamping asrama, memiliki banyak kegiatan yang menyenangkan, sehingga kesejahteraannya meningkat. Faktor pendukung kesejahteraan siswa di sekolah berasrama, yaitu: (1) pengelolaan sekolah yang baik; (2) dukungan sosial; (3) kesempatan pengembangan diri. Sementara faktor penghambat kesejahteraan siswa di sekolah berasrama, yaitu: (1) kebersihan lingkungan sekolah kurang terjaga; (2) terjadi pergantian guru pendamping asrama; (3) konflik dengan teman; (4) merindukan orang tua; (5) konsep diri yang negatif.
Berbeda dengan sekolah asrama, siswa pada sekolah bukan asrama menghabiskan waktunya sebagian hari saja di sekolah. Kendati saat ini banyak sekolah menerapkan model full day school, siswa pada sekolah bukan asrama masih memiliki pengalaman dengan keluarga dan lingkungan tempat tinggalnya sehingga dianggap rentan terkena pengaruh negatif teman sebaya. Perbedaan pengalaman siswa pada sekolah asrama dengan yang bukan asrama akan menimbulkan perbedaan penilaian sehingga diasumsikan terjadi perbedaan kesejahteraan siswa pada kedua model sekolah tersebut.

Sebagian sekolah, baik dengan model asrama maupun bukan asrama, adalah sekolah negeri, yang mana penyelenggaraannya dilakukan oleh pemerintah serta keseluruhan pengelolaan sekolah juga menjadi tanggung jawab pemerintah. Sekolah negeri menjadi pilihan sebagian orang tua untuk menyekolahkan anaknya. Kebanyakan sekolah negeri memiliki prestise lebih bagus dibandingkan dengan sekolah swasta (Beeby, 1982). Sementara itu, sekolah swasta terlalu mahal, karena pembiayaan operasionalnya dibebankan kepada siswa. Keterbatasan dana pemeliharaan seringkali membuat kualitas sekolah swasta menurun. Oleh karena itu, banyak sekolah swasta tidak mampu mempertahankan namanya (Beeby, 1982).

Malang merupakan salah satu kota yang memiliki banyak sekolah asrama. Hal ini tidak lepas dari sebutannya sebagai kota pendidikan. Banyak siswa dari kota lain berminat menuntut ilmu di Malang karena Malang terkenal memiliki banyak sekolah. Sejak saat itu, sekolah dengan model asrama menjadi kebutuhan di Malang (merdeka.com, 2016). Salah satu sekolah negeri dengan model asrama di Malang adalah SMAN Taruna Nala. Sementara sekolah negeri bukan asrama, salah satunya adalah SMAN 3 Malang. SMAN Taruna Nala maupun SMAN 3 Malang sama-sama menjadi sekolah negeri favorit di Malang.

Apabila dihubungkan dengan taraf perkembangan, maka siswa SMA berada pada tahap perkembangan penting, yaitu remaja. Masa remaja merupakan masa peralihan, 
dari kanak-kanak menuju dewasa. Remaja harus meninggalkan segala sesuatu yang bersifat kekanak-kanakkan sekaligus harus mempelajari pola perilaku dan sikap baru untuk menggantikan perilaku dan sikap yang sudah ditinggalkan (Hurlock, 1980: 207). Peralihan peran yang demikian membawa remaja kepada krisis identitas. Krisis identitas seringkali diiringi dengan pola perilaku berisiko. Minumminuman keras, penyalahgunaan obat-obatan, aktivitas seksual, keterlibatan dalam geng, serta penggunaan senjata api cenderung meningkat selama masa remaja, tetapi kebanyakan remaja mengalaminya tanpa masalah (Papalia, Feldman, dan Martorell 2015). Selain itu, remaja juga dihadapkan pada tantangan di masa depan, seperti belajar di perguruan tinggi, kemudian bekerja dengan bekal ilmu pengetahuan, kecakapan, dan keterampilan yang diperoleh saat SMA (Santrock, 1998). Dengan demikian, siswa SMA memiliki harapan besar pada sekolahnya. Sekolah diharapkan dapat menjadi sarana untuk memenuhi kebutuhan dan melewati perubahanperubahan yang sedang ia alami sebagai seorang remaja (Winurini, 2004).

Berdasarkan latar belakang masalah yang telah diuraikan, maka pertanyaan umum yang hendak dijawab melalui tulisan ini adalah: "Apakah ada perbedaan kesejahteraan siswa di sekolah yang signifikan pada siswa SMA Negeri asrama dengan SMA Negeri bukan asrama di Kota Malang?" Lalu, pertanyaan selanjutnya adalah: "Apakah ada perbedaan dalam aspekaspek kesejahteraan siswa di sekolah pada siswa SMA Negeri asrama dengan SMA Negeri bukan asrama di Kota Malang?"

Tujuan dari penelitian ini adalah untuk mengetahui ada atau tidaknya perbedaan kesejahteraan siswa di sekolah pada siswa SMA Negeri asrama dengan yang bukan asrama di Kota Malang. Selain itu, peneliti juga akan melihat ada atau tidaknya perbedaan aspek-aspek kesejahteraan siswa di sekolah pada siswa SMA Negeri asrama dengan yang bukan asrama di Kota Malang.

Hipotesis substansial dalam penelitian ini adalah ada perbedaan yang signifikan dalam kesejahteraan siswa di sekolah pada siswa SMA Negeri asrama dengan siswa SMA Negeri bukan asrama. Sedangkan hipotesis operasionalnya adalah: 1) hipotesis alternatif (ha), yaitu ada perbedaan yang signifikan dalam skor kesejahteraan siswa di sekolah pada siswa SMA Negeri asrama dengan SMA Negeri bukan asrama; 2) hipotesis nol (ho), yaitu tidak ada perbedaan yang signifikan dalam skor kesejahteraan siswa di sekolah pada siswa SMA Negeri asrama dengan SMA Negeri bukan asrama.

Untuk mencapai tujuan penelitian ini, peneliti menggunakan metode kuantitatif. Populasi dalam penelitian adalah siswa SMA yang berasal dari sekolah asrama dan bukan asrama di Kota Malang. Teknik pengambilan sampel yang digunakan adalah accidental sampling. Dalam accidental sampling tidak semua orang dalam populasi mendapat kesempatan untuk menjadi partisipan dalam penelitian (Kumar, 2011). Dalam accidental sampling, partisipan dipilih karena ketersediaan dan kesediaan mereka dalam memberikan respons (Shaughnessy, Zeschmeister, Zeschmeister, 2000). Jadi, setiap siswa SMA yang memenuhi karakteristik partisipan sekolah asrama dan bukan asrama serta bersedia akan menjadi sampel penelitian.

Instrumen yang digunakan dalam penelitian adalah Instrumen School Well Being (SWB) yang dirancang oleh Pratiningtyas (2010). Instrumen ini terdiri dari 25 item mencakup tiga aspek, yaitu aspek kondisi sekolah, hubungan sosial, dan pemenuhan diri. Skala yang digunakan adalah skala tipe Likert, yang mana respons diberikan berdasarkan derajat kesesuaian dengan item-item pernyataan. Setiap item pernyataan terdiri dari enam alternatif jawaban, yaitu: Sangat Setuju, Setuju, Agak Setuju, Agak Tidak Setuju, Tidak Setuju, dan Sangat Tidak Setuju. Alternatif jawaban ini berhubungan dengan pengalaman nyatayang dirasakan partisipanselama bersekolah. Dalam pengisian kuesioner, partisipan diminta untuk memilih satu dari 6 skala yang ada yang paling sesuai dengan keadaan mereka, dalam hal ini kesesuaian dengan pengalaman nyata yang dirasakan partisipan selama bersekolah. 


\section{Kesejahteraan Siswa di Sekolah}

Konsep kesejahteraan siswa di sekolah atau school well being dikembangkan oleh Konu dan Rimpela (2002). Konsep ini menjadi pelengkap teori-teori sebelumnya mengenai kesejahteraan siswa di sekolah, seperti quality of school life, effective school approach, serta health promoting school.

Konsep kesejahteraan siswa di sekolah merujuk pada model konseptual kesejahteraan yang dikemukakan oleh Allardt (tahun?, dalam Konu dan Rimpela, 2002). Ia mendefinisikan kesejahteraan sebagai keadaan yang memungkinkan individu memuaskan kebutuhankebutuhan dasarnya yang mencakup kebutuhan material dan nonmaterial. Konu dan Rimpela (2002) kemudian membagi lagi kebutuhankebutuhan dasar siswa menjadi: (1) kondisi sekolah; (2) hubungan sosial; (3) pemenuhan diri; dan (4) status kesehatan. Pada rumusan konsep kesejahteraan siswa di sekolah selanjutnya, aspek kesehatan dipisahkan dari aspek-aspek lainnya. Aspek kesejahteraan siswa di sekolah menjadi kondisi sekolah, hubungan sosial, dan pemenuhan diri (Konu dan Rimpela, 2002). Dengan begitu, pengertian kesejahteraan siswa di sekolah adalah penilaian seseorang terhadap diri mereka sendiri dan hubungannya dengan lingkungan sekolah, di mana ia dapat memuaskan kebutuhan-kebutuhan dasarnya, yaitu kondisi sekolah, hubungan sosial, dan pemenuhan diri.

Aspek kondisi sekolah mencakup kondisi fisik sekitar sekolah dan lingkungan di dalam sekolah, mata pelajaran dan jadwal sekolah, hukuman, pelayanan di sekolah (kantin, UKS, perpustakaan, dan layanan konseling). Aspek hubungan sosial berkaitan dengan kegiatan bersosialisasi dengan orang lain dan pembentukkan identitas sosial. Aspek hubungan sosial merujuk pada iklim sekolah, dinamika kelompok, hubungan antara guru dan siswa, hubungan dengan teman sebaya, serta hubungan antara rumah dan sekolah. Sementara itu, aspek pemenuhan diri berbicara tentang bagaimana sekolah menciptakan kemungkinan-kemungkinan untuk pemenuhan diri siswanya. Setiap siswa diberikan kesempatan yang sama sebagai bagian dari komunitas sekolah. Hal ini memungkinkan setiap siswa ikut berpartisipasi dalam pengambilan keputusan serta mengembangkan pengetahuan dan keterampilan berdasarkan minatnya. Aspek akan pemenuhan diri siswa dapat diwakili dengan penghargaan terhadap hasil kerja siswa, bimbingan dan dorongan yang diberikan oleh guru, peningkatan

WAKTU

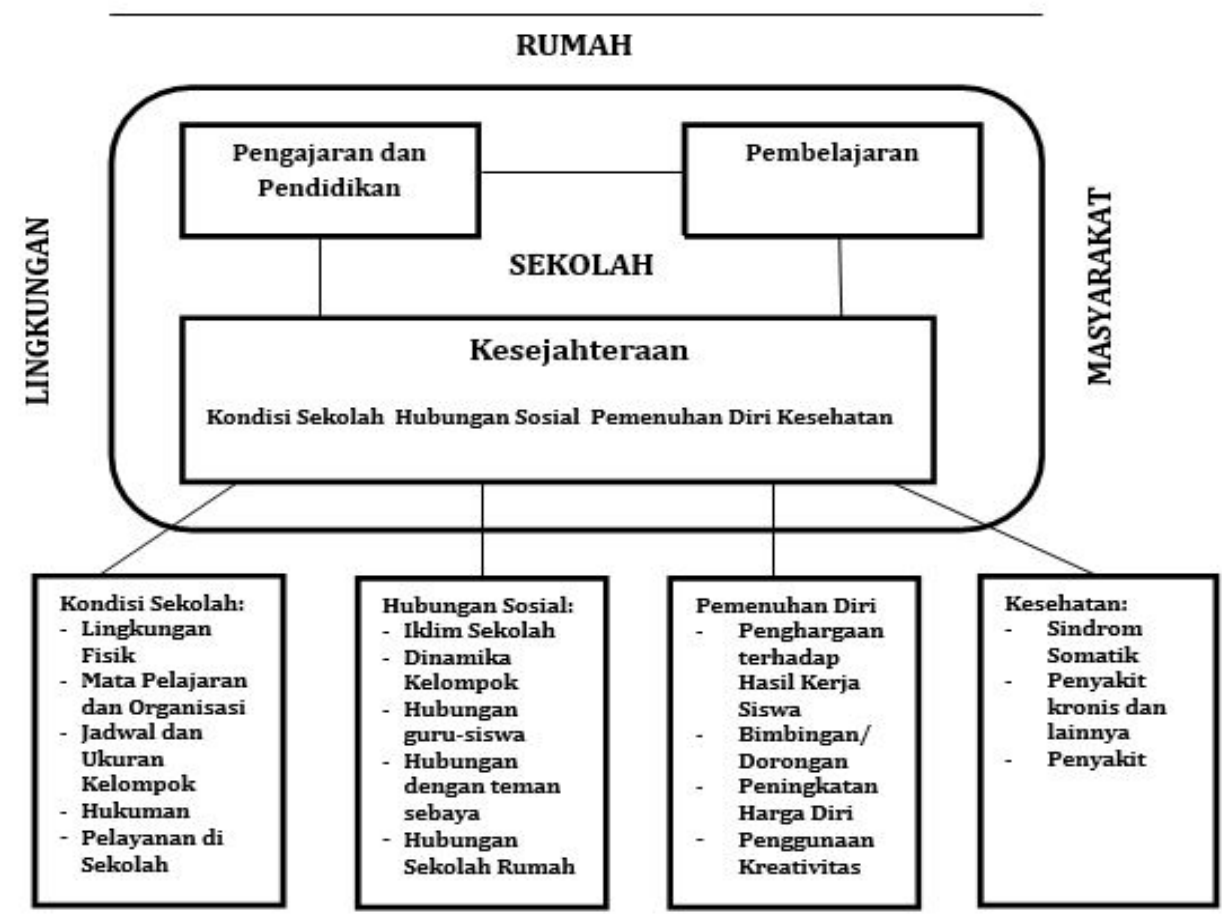

Gambar 1. Kesejahteraan Siswa di Sekolah 
harga diri, serta penggunaan kreativitas (Konu dan Rimpela, 2002).

Gambar 1 menunjukkan bahwa kesejahteraan, pengajaran, dan pendidikan, serta pembelajaran berkaitan satu sama lain. Pengajaran dan pendidikan memiliki hubungan dengan pembelajaran. Seorang siswa dapat mengalami proses pembelajaran melalui pengajaran dan pendidikan yang ia terima di sekolah. Kemudian, pengajaran, pendidikan, serta pembelajaran akan memengaruhi setiap aspek dalam kesejahteraan, yaitu aspek kondisi sekolah, hubungan sosial, dan pemenuhan diri. Kesejahteraan siswa di sekolah akan terpenuhi apabila pengajaran dan pendidikan yang terdapat di sekolah menyediakan sarana untuk memenuhi hal tersebut, yang nantinya akan mempengaruhi proses pembelajaran dalam diri siswa. Dalam hal ini, komunitas dan lingkungan masyarakat di sekitar siswa ikut memiliki pengaruh terhadap sekolah dan siswa (Konu dkk, 2002 dalam Praningtyas, 2010).

\section{Gambaran Umum Partisipan}

Penelitian ini dilakukan di Kota Malang pada tanggal 19 hingga 26 Juli 2018. Jumlah kuesioner yang disebar dalam penelitian ini sebanyak 187 kuesioner. Namun karena ada partisipan yang tidak mengisi kuesioner secara lengkap, maka jumlah kuesioner yang digunakan dalam pengolahan data menjadi sebanyak 186 kuesioner, terdiri dari 89 kuesioner dari SMAN bukan asrama dan 97 kuesioner dari SMAN asrama. Gambaran karakteristik partisipan meliputi jenis kelamin, usia, kelas, dan jurusan dapat dilihat pada Tabel 1.

Tabel 1. Profil Partisipan

\begin{tabular}{|c|c|c|c|c|c|c|c|}
\hline \multirow[t]{2}{*}{ Karakteristik } & \multicolumn{2}{|c|}{$\begin{array}{c}\text { SMAN } \\
\text { Bukan Asrama }\end{array}$} & \multicolumn{3}{|c|}{$\begin{array}{l}\text { SMAN } \\
\text { Asrama }\end{array}$} & \multicolumn{2}{|c|}{ Total Keseluruhan } \\
\hline & Frekuensi & $\%$ & & & $\%$ & Frekuensi & $\%$ \\
\hline \multicolumn{8}{|l|}{ Jenis Kelamin } \\
\hline Laki-laki & 22 & 24,7 & 38 & 39,2 & & 60 & 32,3 \\
\hline Perempuan & 66 & 74,2 & 52 & 53,6 & & 118 & 63,4 \\
\hline Tidak Diketahui & 1 & 1,1 & 7 & 7,2 & & 8 & 4,3 \\
\hline \multicolumn{8}{|l|}{ Usia } \\
\hline 14 tahun & 1 & 1,1 & 0 & 0 & & 1 & 0,5 \\
\hline 15 tahun & 9 & 10,1 & 9 & 9,3 & & 18 & 9,7 \\
\hline 16 tahun & 47 & 52,8 & 50 & 51,5 & & 97 & 52,2 \\
\hline 17 tahun & 28 & 31,5 & 34 & 35,1 & & 62 & 33,3 \\
\hline 18 tahun & 4 & 4,5 & 4 & 4,1 & & 8 & 4,3 \\
\hline \multicolumn{8}{|l|}{ Kelas } \\
\hline 10 & 0 & 0 & 1 & 1 & & 1 & 0,5 \\
\hline 11 & 42 & 47,1 & 52 & 53,6 & & 94 & 50,5 \\
\hline 12 & 32 & 36 & 44 & 45,4 & & 76 & 40,9 \\
\hline Tidak Diketahui & 15 & 16,9 & 0 & 0 & & 15 & 8,1 \\
\hline \multicolumn{8}{|l|}{ Jurusan } \\
\hline IPA & 54 & 60,7 & 49 & 50,5 & & 103 & 55,4 \\
\hline IPS & 34 & 38,2 & 48 & 49,5 & & 82 & 44,1 \\
\hline Tidak Diketahui & 1 & 1,1 & 0 & 0 & & 1 & 0,5 \\
\hline
\end{tabular}


Berdasarkan Tabel 1, dapat dilihat bahwa lebih dari setengah partisipan adalah berjenis kelamin perempuan $(63,4 \%)$ dan mengambil jurusan IPA $(55,4 \%)$. Rentang usia partisipan dalam penelitian ini cukup lebar, yaitu 14-18 tahun, dengan sebagian besar partisipan berada pada usia 16 tahun (52,2\%). Partisipan yang ikut serta dalam penelitian ini berasal dari kelas X hingga XII, dan siswa kelas XI (50,5 \%) merupakan partisipan terbanyak.

Lebih lanjut, partisipan yang terlibat dalam penelitian ini adalah siswa SMAN Taruna Nala dan SMAN 3 Malang. Kedua sekolah ini merupakan sekolah negeri di Kota Malang, dan sama-sama sekolah favorit. Perbedaannya, SMAN Taruna Nala merupakan sekolah dengan model asrama, sementara SMAN 3 Malang merupakan sekolah bukan asrama.

SMAN Taruna Nala merupakan pecahan dari SMAN 10 Malang, diresmikan oleh Presiden RI, Ir. Joko Widodo pada tanggal 3 Januari 2017. SMAN Taruna Nala adalah sekolah negeri unggulan berasrama yang dikelola oleh Pemerintah Provinsi Jawa Timur berdasarkan Surat Keputusan Kepala Dinas Pendidikan Provinsi Jawa Timur No.188.4/615/101/2017 tanggal 27 Januari 2017 tentang Penetapan Pendirian Lembaga SMA Negeri Taruna Nala Jawa Timur. SMAN Taruna Nala dibentuk untuk menjawab tantangan masa depan di era global yang membutuhkan pemimpin yang unggul di bidang akademik dan nonakademik, memiliki kemandirian dan berkarakter kebangsaan yang kuat (Pemprov Jawa Timur, Dinas Pendidikan, SMAN Taruna Nala, 2018).

Sistem pendidikan berasrama yang diterapkan SMAN Taruna Nala memberikan penguatan nilai-nilai religius, kemandirian, tanggung jawab, tangguh, toleransi, berjiwa sosial, berbudi luhur, berjiwa kepemimpinan, dan jujur, serta memiliki karakter kebangsaan yang kuat. Programprogram untuk siswa juga banyak dikembangkan di sekolah ini, antara lain program kewirausahaan, program kecakapan hidup, program pengabdian masyarakat, dan lain-lain (Pemprov Jawa Timur, Dinas Pendidikan, SMAN Taruna Nala, 2018).

Selain Kurikulum Nasional 2013, SMAN
Taruna Nala menggunakan Kurikulum Khusus Bela Negara dan Kemaritiman yang diampu oleh TNI Angkatan Laut. Kurikulum Khusus Bela Negara dan Kemaritiman tersebut meliputi: (1) aspek pengetahuan tentang bela negara, wawasan nusantara, ketahanan nasional, wawasan kemaritiman, kepemimpinan, komunikasi, etika, peraturan umum kehidupan sekolah, dan tata upacara; (2) aspek keterampilan, yaitu kesehatan jasmani (lari, push up, sit up, pull up, shuttle run), keterampilan jasmani (bela diri karate dan renang), pendidikan baris-berbaris, marching band, serta outbond; (3) aspek bimbingan dan pengasuhan yang terdiri atas pengenalan diri, pengembangan karakter, pengembangan kepemimpinan, kerjasama kelompok, manajemen resiko, dan tradisi atau kebiasaan-kebiasaan baik dalam kehidupan berasrama dan sekolah yang dibimbing dan dipantau terus-menerus selama 24 jam dari bangun hingga tidur kembali (Pemprov Jawa Timur, Dinas Pendidikan, SMAN Taruna Nala, 2018).

SMAN 3 Malang berdiri pada tanggal 8 Agustus 1952 berdasarkan Surat Keputusan Menteri PP dan K Nomor 3418/B tertanggal 8 Agustus 1953. Dalam sejarahnya, SMAN 3 Malang mengalami beberapa kali perubahan hingga terakhir kembali menjadi SMAN 3 Malang. SMAN 3 Malang menerapkan full day school, kegiatannya mulai pukul 06.45-15.15 WIB di hari Senin hingga Kamis, pukul 06.4515.00 WIB di hari Jumat, dan 06.45-09.00 WIB di hari Sabtu. Adapun kurikulum yang digunakan yaitu Kurikulum Nasional 2013.

SMAN 3 Malang berupaya menjadi sekolah unggul yang memiliki civitas akademika beriman, bertaqwa, berakhlaqul karimah, berprestasi, berperan aktif dalam era global dan peduli pada lingkungan. Adapun nilai-nilai yang dikembangkan, yaitu: religius, jujur, berprestasi, bertanggung jawab, kerjasama, aktif, kreatif, inovatif, berpikir kritis, rasa senang, persahabatan, kebijaksanaan, keseimbangan hidup (SMAN 3 Malang, 2018).

SMAN 3 Malang memiliki beberapa program unggulan, salah satunya adalah International Competitions and Assessments for Schools 
(ICAS). ICAS dilaksanakan mulai tahun 2014, tujuannya adalah untuk mengapresiasi prestasi siswa yang berhasil mengikuti ICAS pada setiap subjek yang diikuti (English, Mathematics, Science, Writing, Computer Skills). Selain itu, ada juga program Microsoft Testing Center. SMAN 3 Malang merupakan satu-satunya SMA di Indonesia yang menjadi pusat pengambilan tes Microsoft yang bisa diikuti oleh siswa dan pendidik di seluruh Indonesia. Program lainnya adalah Student Exchange dan International Leadership Seminar. Program ini dilakukan dengan sekolah-sekolah mitra yang sudah menandatangani MOU. Kemudian ada Program Bedhol Bhawikarsu, yaitu kegiatan bakti sosial plus yang ditujukan untuk mendekatkan seluruh elemen SMAN 3 Malang pada masyarakat pedesaan. Kegiatan ini diisi dengan bakti sosial berupa pemberian bantuan, penyuluhan, pendidikan, serta pemeriksaan kesehatan secara gratis. Selain itu, ada Program Pagelaran Seni Citra Smanti (PSCS). PSCS adalah wadah bagi siswa SMAN 3 Malang untuk menunjukkan kreativitasnya dalam bidang seni dan budaya kepada masyarakat luas (sman3-malang.sch.id, 2018).

\section{Skor Kesejahteraan Siswa pada SMAN Asrama dan SMAN Bukan Asrama}

Rata-rata skor kesejahteraan siswa seluruh partisipan adalah 106,45 dengan skor terendah adalah 67 dan skor tertinggi adalah 132. Skor terendah pada SMAN asrama adalah 78, sedangkan skor tertingginya adalah 131. Skor terendah pada SMAN bukan asrama adalah 67, sedangkan skor tertingginya adalah 132 .

Selain skor yang telah disebutkan sebelumnya, peneliti membuat kategorisasi skor dengan membuat norma alat ukur berdasarkan nilai $\mathrm{Z}$ skor yang diperoleh dari nilai rata-rata dan standar deviasi. Norma dibuat menjadi tiga kategori, yaitu rendah untuk nilai yang berada di bawah -1 SD dari rata-rata, sedang untuk nilai yang berada di antara -1 SD dan +1 SD dari rata-rata, dan tinggi untuk nilai yang berada di atas +1 SD dari rata-rata. Norma skor dapat dilihat pada Tabel 2.

Tabel 2 menunjukkan gambaran partisipan pada SMAN asrama paling banyak pada tingkat kesejahteraan siswa sedang, yaitu sebanyak 71 $\%$. Sedangkan partisipan SMAN asrama paling sedikit berada pada tingkat kesejahteraan siswa rendah, yaitu sebanyak $8 \%$.

Sama halnya dengan partisipan pada SMAN asrama, partisipan pada SMAN bukan asrama paling banyak berada pada tingkat kesejahteraan siswa sedang, yaitu sebanyak 57\%. Sedangkan partisipan SMAN bukan asrama paling sedikit berada pada tingkat kesejahteraan siswa tinggi, yaitu sebanyak $7 \%$

Dengan berada pada tingkat kesejahteraan siswa sedang, dapat disimpulkan bahwa baik siswa pada SMAN asrama maupun bukan asrama memiliki penilaian terhadap dirinya sendiri dan hubungannya dengan lingkungan sekolah yang cukup. Hasil skor kesejahteraan siswa per aspek pada Tabel 3 menunjukkan bahwa ketiga aspek kesejahteraan siswa di sekolah, yaitu kondisi sekolah, hubungan sosial, dan pemenuhan diri, baik pada SMAN asrama mapun SMAN bukan asrama, memiliki skor rata-rata yang tergolong sedang. Dengan demikian, dapat dikatakan bahwa siswa, baik pada SMAN asrama maupun bukan asrama, menilai sekolahnya telah memenuhi aspek-aspek dalam kesejahteraan siswa di sekolah, yaitu aspek kondisi sekolah, hubungan sosial, dan pemenuhan diri.

Tabel 2. Penggolongan Skor Kesejahteraan Siswa di Sekolah

\begin{tabular}{|c|c|c|c|c|c|}
\hline \multirow{2}{*}{ Rentang Skor } & \multirow{2}{*}{ Tingkat Kesejahteraan Siswa di Sekolah } & \multicolumn{2}{|c|}{ SMAN Asrama } & \multicolumn{2}{|c|}{ SMAN Bukan Asrama } \\
\hline & & Frekuensi & $\%$ & Frekuensi & $\%$ \\
\hline $119-150$ & Tinggi & 20 & 21 & 6 & 7 \\
\hline $95-118$ & Sedang & 69 & 71 & 57 & 64 \\
\hline $25-94$ & Rendah & 8 & 8 & 26 & 29 \\
\hline
\end{tabular}


Tabel 3. Penggolongan Skor Aspek Kesejahteraan Siswa di Sekolah

\begin{tabular}{|c|c|c|c|c|c|c|c|c|}
\hline \multirow{2}{*}{$\begin{array}{l}\text { Aspek Kesejahte-raan } \\
\text { Siswa di Sekolah }\end{array}$} & \multirow{2}{*}{$\begin{array}{l}\text { Rentang } \\
\text { Skor }\end{array}$} & \multirow[t]{2}{*}{ Tingkat } & \multicolumn{3}{|c|}{ SMAN Asrama } & \multicolumn{3}{|c|}{ SMAN Bukan Asrama } \\
\hline & & & Frekuensi & $\%$ & Mean & Frekuensi & $\%$ & Mean \\
\hline \multirow[t]{3}{*}{ Kondisi Sekolah } & $41-54$ & Tinggi & 21 & 22 & 37,75 & 4 & 5 & 31,01 \\
\hline & $29-40$ & Sedang & 76 & 78 & & 50 & 56 & \\
\hline & $9-28$ & Rendah & 0 & 0 & & 35 & 39 & \\
\hline \multirow[t]{3}{*}{ Hubungan Sosial } & $40-48$ & Tinggi & 11 & 11 & 34,94 & 8 & 9 & 34,93 \\
\hline & $31-39$ & Sedang & 72 & 74 & & 69 & 78 & \\
\hline & $8-30$ & Rendah & 14 & 15 & & 12 & 13 & \\
\hline \multirow[t]{3}{*}{ Pemenuhan Diri } & $42-48$ & Tinggi & 17 & 18 & 37,93 & 10 & 11 & 35,96 \\
\hline & $33-41$ & Sedang & 72 & 74 & & 60 & 67 & \\
\hline & $8-32$ & Rendah & 8 & 8 & & 19 & 21 & \\
\hline
\end{tabular}

Perbedaan Skor Kesejahteraan Siswa di Sekolah Antara SMAN Asrama dan SMAN Bukan Asrama

Untuk melihat perbedaan kesejahteraan siswa di sekolah antara siswa yang berada pada SMAN asrama dan siswa yang berada pada SMAN bukan asrama, peneliti menggunakan rumus Fisher's t. Sementara itu, analisis statistik dalam penelitian ini dilakukan dengan LOS 0.05, artinya kemungkinan kesalahan yang terjadi adalah 5 dalam setiap 100 kasus. Jika skor hasil perhitungan statistik melebihi 0.05 , maka hipotesis nol ditolak dan hipotesis alternatif diterima. Artinya ada perbedaan kesejahteraan siswa di sekolah yang signifikan antara siswa yang berada pada SMAN asrama dan siswa yang berada pada SMAN bukan asrama. Sebaliknya, jika skor hasil perhitungan statistik kurang dari 0.05, maka hipotesis nol diterima dan hipotesis alternatif ditolak. Artinya, tidak ada perbedaan yang signifikan antara siswa yang berada pada SMAN asrama dan siswa yang berada pada SMAN bukan asrama.

Tabel 4 menunjukkan, hasil perhitungan t-test adalah sebesar 5,29 dengan signifikansi sebesar $0,00(t=5,29 ; p<0,05)$. Nilai signifikansi sebesar ini signifikan pada LOS 0,05, artinya hipotesis nol ditolak dan hipotesis alternatif diterima. Dengan demikian, maka ada perbedaan kesejahteraan siswa di sekolah yang signifikan pada siswa SMAN asrama dengan SMAN bukan asrama.

Tabel 4 juga menunjukkan, adanya perbedaan rata-rata skor, yaitu sebesar 8,72 dengan ratarata skor SMAN asrama adalah 110,62 dan ratarata skor SMAN bukan asrama adalah 101,9. Artinya, berdasarkan hasil tersebut, maka dapat disimpulkan bahwa kesejahteraan siswa di sekolah pada siswa SMAN asrama lebih baik dibanding siswa SMAN bukan asrama.

Tabel 4. Perbedaan Kesejahteraan Siswa di Sekolah Secara Umum

\begin{tabular}{|c|c|c|c|c|c|c|c|}
\hline \multirow[t]{2}{*}{ Variabel } & \multicolumn{2}{|c|}{$\begin{array}{c}\text { SMAN Bukan } \\
\text { Asrama }(\mathbf{N}=89)\end{array}$} & \multicolumn{2}{|c|}{$\begin{array}{c}\text { SMAN Asrama } \\
(\mathbf{N}=97)\end{array}$} & \multirow{2}{*}{$\begin{array}{c}\text { Perbedaan } \\
\text { Mean }\end{array}$} & \multirow{2}{*}{$T$} & \multirow[t]{2}{*}{$\mathbf{p}$} \\
\hline & $\mathbf{M}$ & SD & $\mathbf{M}$ & SD & & & \\
\hline $\begin{array}{l}\text { Kesejahteraan Siswa di } \\
\text { Sekolah }\end{array}$ & 101,9 & 12,16 & 110,62 & 10,10 & 8,72 & 5,29 & 0,00 \\
\hline
\end{tabular}


Tabel 5. Perbedaan Aspek School Well Being

\begin{tabular}{|c|c|c|c|c|c|c|c|}
\hline \multirow[t]{2}{*}{ Aspek } & \multicolumn{2}{|c|}{$\begin{array}{c}\text { SMAN Bukan Asrama } \\
(\mathbf{N}=\mathbf{8 9})\end{array}$} & \multicolumn{2}{|c|}{$\begin{array}{l}\text { SMAN Asrama } \\
(\mathbf{N}=97)\end{array}$} & \multirow[t]{2}{*}{$\begin{array}{c}\text { Perbedaan } \\
\text { Mean } \\
\end{array}$} & \multirow[t]{2}{*}{$\mathbf{t}$} & \multirow{2}{*}{$\mathbf{p}$} \\
\hline & $\mathbf{M}$ & SD & $\mathbf{M}$ & SD & & & \\
\hline Kondisi Sekolah & 31,01 & 6,05 & 37,75 & 3,50 & 6,74 & 9,19 & 0,00 \\
\hline Hubungan Sosial & 34,93 & 4,03 & 34,94 & 4,22 & 0,01 & 0,01 & 0,99 \\
\hline Pemenuhan Diri & 35,96 & 4,57 & 37,93 & 4,30 & 1,97 & 3,03 & 0,003 \\
\hline
\end{tabular}

Tabel 5 menunjukkan, perbedaan ratarata skor aspek kesejahteraan siswa paling tinggi berada pada aspek kondisi sekolah, yaitu sebesar 6,74. Sedangkan perbedaan rata-rata skor kesejahteraan siswa paling rendah berada pada aspek hubungan sosial, yaitu sebesar 0,01. Lebih lanjut, baik pada SMAN asrama maupun SMAN bukan asrama, rata-rata skor tertinggi di antara ketiga aspek kesejahteraan siswa adalah aspek pemenuhan diri. Rata-rata skor pemenuhan diri pada SMAN asrama sebesar 37,93, sementara rata-rata skor pemenuhan diri pada SMAN bukan asrama sebesar 35,96. Hal ini menunjukkan bahwa mayoritas partisipan melihat bahwa pemenuhan diri saat berada di sekolah merupakan hal yang paling penting dalam penilaian mereka terhadap diri sendiri dan hubungannya dengan sekolah. Partisipan menilai sekolah telah memberikan kesempatan pada mereka untuk memenuhi kebutuhan diri mereka, antara lain memberikan penghargaan terhadap hasil kerja mereka, mendapatkan bimbingan dan dorongan dari guru, peningkatan harga diri, dan kesempatan penggunaan kreativitas.

Tabel 5 juga menunjukkan bahwa rata-rata skor kondisi sekolah pada SMAN asrama hampir sama besarnya dengan rata-rata skor pemenuhan diri, yaitu sebesar 37,75. Namun demikian, pada SMAN bukan asrama, rata-rata skor kondisi sekolah justru paling rendah di antara ketiga aspek yang lain, yaitu sebesar 31,01. Hal ini menunjukkan bahwa mayoritas siswa SMAN bukan asrama menilai bahwa kondisi sekolah kurang penting dalam hubungannya terhadap penilaian mereka terhadap diri mereka sendiri dan hubungannya dengan sekolah. Berbeda halnya dengan siswa SMAN asrama. Siswa pada SMAN asrama menganggap bahwa kondisi sekolah masih menjadi aspek yang penting dalam hubungannya terhadap penilaian mereka terhadap diri mereka sendiri dan hubungannya dengan sekolah.

Dengan melihat pada Tabel 5, dapat diketahui pula bahwa untuk tiap-tiap aspeknya, siswa SMAN asrama memiliki rata-rata skor aspek kesejahteraan siswa lebih tinggi dibanding siswa SMAN bukan asrama. Artinya, jika dilihat secara per aspek kesejahteraan siswa di sekolah, siswa SMAN asrama merasa lebih baik dibanding siswa SMAN bukan asrama.

Berdasarkan perhitungan t-test untuk tiaptiap aspek kesejahteraan siswa di sekolah, diperoleh hasil 9,$19 ; 0,01 ; 3,03$ untuk aspek kondisi sekolah, hubungan sosial, dan pemenuhan diri. Signifikansi untuk aspek kondisi sekolah dan pemenuhan diri adalah di bawah 0,05. Hanya signifikansi aspek hubungan sosial berada di atas 0,05 . Artinya, ada perbedaan aspek kondisi sekolah dan pemenuhan diri yang signifikan pada siswa SMAN asrama dengan siswa SMAN bukan asrama. Sebaliknya, pada aspek hubungan sosial, tidak ada perbedaan signifikan pada siswa SMAN asrama dengan SMAN bukan asrama.

Adanya perbedaan kesejahteraan siswa yang signifikan antara siswa SMAN asrama dengan siswa SMAN bukan asrama bisa dijelaskan sebagai berikut. Sekolah asrama dan bukan asrama adalah dua model sekolah yang memiliki perbedaan karakteristik yang khas. Sekolah asrama adalah model sekolah yang mewajibkan siswanya untuk menginap selama bersekolah di sekolah tersebut atau dengan waktu yang ditentukan sekolah tersebut (Dimyati dalam Kurniasih, 2017). Dengan model asrama, sekolah berusaha menerapkan program pendidikan yang komprehensif-holistik terhadap siswa melalui berbagai aktivitas pembelajaran sesuai dengan visi misi dari sekolah tersebut. Hal ini didasari konsep awal pembentukan sekolah asrama, yaitu: untuk menjawab kekurangan sekolah bukan asrama 
yang dianggap terkonsentrasi pada kegiatankegiatan akademik, kurang menyentuh aspek lain dari kehidupan siswa akibat keterbatasan waktu sekolah.

Martin, Papworth, Ginns, dan Liem (2014) mengulas beberapa perbedaan sekolah asrama dengan yang bukan asrama. Sepanjang hari siswa pada sekolah asrama melakukan beragam kegiatan, seperti belajar, mengerjakan tugas, bermain, hingga tidur di sekolah. Hal ini menciptakan kekhasan kondisi dan interaksi sosial dalam lingkungan sekolah asrama. Siswa asrama terikat dalam rangkaian kegiatan yang beragam serta memiliki kesempatan yang lebih banyak untuk berinteraksi dengan orang-orang yang ada di sekolah dan asrama, seperti teman sebaya, guru, pegawai sekolah, pengasuh asrama, dan lain sebagainya. Dibanding siswa biasa, siswa asrama memiliki peluang lebih besar untuk mengembangkan hubungan pribadi dengan orang-orang yang ada di sekolah asrama tersebut (The Association of Boarding Schools, 2013). Dengan kata lain, lingkungan sekolah asrama menyediakan peluang yang berbeda bagi siswa untuk tumbuh dan berkembang (Bronfenbrenner, 1970; Holden et al., 2010).

Kekhasan lain dari sekolah asrama adalah pengawasan yang intensif. Sekolah asrama membawa siswa jauh dari rumah tetapi berupaya menyediakan lingkungan yang lebih stabil, lebih aman, dibandingkan denganrumah atau komunitas di mana mereka tinggal sebelumnya (Scott dan Langhorne, 2012). Apabila dibandingkan dengan sekolah biasa, kehidupan sekolah asrama melibatkan sistem regulasi yang detail serta jadwal harian yang ketat, misalnya seperti kapan siswa harus bangun atau tidur, makan, belajar, mencuci pakaian, termasuk berkegiatan di waktu senggang. Peraturan memberi penjelasan mengenai bagaimana, kapan, dan dimana siswa harus menyelesaikan pekerjaan rumah mereka, mengenai standar kerapihan dalam penyimpanan barang-barang, di samping mengenai tata cara akses telepon dan komputer (Cookson, 2009; Cree, 2000; B. R. Lee \& Barth, 2009; Williams, 2011). Hal ini juga yang kemudian mendasari banyak orang tua, terutama orang tua dengan banyak kesibukan, memilih sekolah asrama untuk menyekolahkan anak-anaknya.

Tampak bahwa sekolah asrama mengembangkan identitas kolektif, melalui tradisi, ritual, dan simbol yang diasosiasikan dengan rumah asrama di dalam sekolah atau tradisi asrama di dalam sekolah sebagai suatu kesatuan. Dengan demikian, sekolah asrama melahirkan konteks ekologis yang spesifik dan simbolik yang mengikat individu kepada kolektif (Chase, 2008; Finn, 2012; GaztambideFerna'ndez, 2009; Khan, 2010).

Perbedaan karakteristik antara sekolah asrama dengan yang bukan asrama menimbulkan perbedaan pengalaman yang kemudian berpengaruh terhadap perbedaan persepsi pada siswa di kedua sekolah tersebut. Penilaian siswa di dalam kesejahteraan siswa di sekolah merupakan salah satu bentuk dari persepsi. Persepsi adalah pengalaman fenomenologis dari suatu obyek atau situasi (Allport dalam Shaver, 1981). Baron, Brascombe, Byrne (2008) mengatakan bahwa persepsi terbentuk berdasarkan impresi seseorang mengenai orang lain atau objek tertentu. Dalam kesejahteraan siswa di sekolah, persepsi siswa berkenaan dengan penilaiannya terhadap diri mereka sendiri dan hubungannya dengan lingkungan sekolah, di mana ia dapat memuaskan kebutuhan-kebutuhan dasarnya, yaitu kondisi sekolah, hubungan sosial, dan pemenuhan diri. Penilaian ini merupakan hasil pemahaman siswa mengenai sekolahnya dan segala sesuatu berkaitan dengan sekolahnya. Dengan demikian, perbedaan karakteristik yang terdapat pada sekolah asrama dan sekolah bukan asrama dapat dikatakan mengawali perbedaan kesejahteraan pada siswa di kedua sekolah tersebut.

Hasil penelitian yang lain menunjukkan bahwa sekolah asrama memiliki tingkat kesejahteraan siswa lebih tinggi dibanding sekolah bukan asrama, bahkan untuk setiap aspeknya. Dilihat dari aspek kondisi sekolah, sekolah asrama menyediakan sarana dan prasarana yang lengkap bagi siswanya. Selain fasilitas belajarmengajar, tersedia fasilitas hunian dan juga fasilitas pendukung. Lengkapnya fasilitas pada 
sekolah asrama ditujukan untuk menunjang program pendidikan yang komprehensif-holistik, sekaligus untuk memastikan kenyamanan dan keamanan siswa supaya bisa lebih fokus belajar meski jauh dari keluarga. Program pendidikan yang komprehensif-holistik juga tampak dari penggunaan waktu belajar yang lebih banyak dari siswa pada sekolah biasa. Waktu setelah jam sekolah digunakan oleh siswa untuk memperdalam materi bersama kelompok. Ada kelompok yang memanfaatkan guru piket untuk mengajar, ada juga yang memanggil guru privat dari luar. Berdasarkan wawancara dengan beberapa siswa di sekolah asrama, banyaknya waktu yang digunakan untuk belajar tidak membebani mereka, bahkan justru memenuhi harapannya. Hal ini bisa dipahami karena siswa yang masuk ke sekolah asrama ini adalah siswa berprestasi yang umumnya memiliki hasrat berprestasi tinggi.

Pada SMAN bukan asrama, sarana dan prasarana memang sudah cukup, layaknya standar sekolah umum, tetapi tidak selengkap sekolah asrama. Selain itu, meskipun pernah menyandang sebagai sekolah unggulan, namun peraturan terbaru mengenai sistem zonasi telah memaksa sekolah untuk menerima siswa dari latar belakang prestasi yang beragam. Hal ini memengaruhi proses pembelajaran. Sebagian siswa bisa saja kesulitan menangkap materi ajar dengan ritme pembelajaran yang sudah terbentuk bertahun-tahun sebagai sekolah unggulan. Perbedaan kondisi seperti ini bisa menjelaskan adanya perbedaan rata-rata skor yang menonjol pada aspek kondisi di antara kedua sekolah tersebut.

Perbedaan lain adalah pada aspek pemenuhan diri. Temuan Bronfenbrenner (1994) mengungkapkan bahwa siswa pada sekolah asrama memiliki banyak kesempatan terlibat dalam struktur dan proses sekolah sehingga menjadikan sekolah asrama sebagai lingkungan yang berpengaruh dalam kehidupan siswa. Selain itu, kesempatan guru untuk membimbing siswa juga lebih banyak karena siswa memiliki waktu yang lebih banyak di sekolah. Di samping guru, ada juga pengasuh yang memberikan pengasuhan dan pembinaan karakter di luar jam pelajaran untuk memaksimalkan potensi perkembangan diri. Keterlibatan siswa dalam struktur dan proses sekolah serta banyaknya kesempatan guru dan pengasuh memberikan bimbingan dan dorongan menciptakan kemungkinan bagi siswa sekolah asrama untuk memenuhi kebutuhan pada aspek pemenuhan diri.

Kendati ada perbedaan, aspek pemenuhan diri dinilai paling penting di antara aspek lainnya oleh siswa pada kedua sekolah tersebut. Baik SMAN Taruna Nala maupun SMAN 3 Malang memiliki program dan kegiatan yang memungkinkan siswa mengembangkan pengetahuan dan keterampilannya. Kegiatan ekstrakurikuler contohnya. Kedua sekolah tersebut memiliki kegiatan ekstrakurikuler yang beragam, jumlahnya kurang lebih ada sebanyak 20, disesuaikan dengan minat kebanyakan siswa. Selain kegiatan ekstrakurikuler, kedua sekolah juga sama-sama memiliki program unggulan. SMAN Taruna Nala memiliki program, antara lain program kewirausahaan, program kecakapan hidup, program pengabdian masyarakat, dan lain-lain. Sedangkan SMAN 3 Malang memiliki program, seperti International Competitions and Assessments for Schools (ICAS), Student Exchange dan International Leadership Seminar, Program Bedhol Bhawikarsu, Program Pagelaran Seni Citra Smanti (PSCS). Programprogram ini ditujukan untuk mengapresiasi keterampilan siswa, mendorong kreativitas siswa, meningkatkan kapasitas siswa sebagai makhluk sosial.

Tidak seperti aspek kondisi sekolah dan pemenuhan diri, aspek hubungan sosial tidak memiliki perbedaan signifikan di antara kedua sekolah tersebut. Kendati berbeda model, kedua sekolah tersebut sama-sama sekolah negeri, yang mana penyelenggara dan pengelolanya adalah pemerintah provinsi, sesuai dengan UU No.23 Tahun 2014 tentang Pemerintah Daerah. Selain itu, SMAN Taruna Nala yang sebelumnya adalah SMAN 10 Malang baru berdiri di awal tahun 2017. Artinya, iklim sekolah negeri biasa masih terasa pada SMAN Taruna Nala. Berdasar penjelasan salah satu guru di SMAN Taruna Nala, hubungan 
antara guru dan siswa tidak seformal sekolah asrama pada umumnya. Hubungan antara guru dan siswa lebih kepada hubungan kekeluargaan. Hubungan guru dan siswa seperti ini juga sama ditunjukkan pada sekolah biasa.

\section{Penutup}

\section{Simpulan}

Hasil penelitian menunjukkan bahwa ada perbedaan kesejahteraan yang signifikan pada siswa SMAN asrama dengan SMAN bukan asrama. Lebih spesifik lagi, ada perbedaan aspek kondisi sekolah dan pemenuhan diri yang signifikan pada siswa SMAN asrama dengan siswa SMAN bukan asrama. Sebaliknya, pada aspek hubungan sosial, tidak ada perbedaan signifikan pada siswa SMAN asrama dengan SMAN bukan asrama. Dilihat dari rata-rata skor kesejahteraan siswa di kedua sekolah tersebut, baik rata-rata skor secara umum maupun hingga ke aspeknya, kesejahteraan siswa pada SMAN asrama lebih baik dibanding siswa pada SMAN bukan asrama.

Hasil penelitian lain menunjukkan, siswa pada SMAN asrama maupun SMAN bukan asrama, memiliki tingkat kesejahteraan sedang. Dengan demikian, baik siswa pada SMAN asrama maupun bukan asrama, memiliki penilaian terhadap dirinya sendiri dan hubungannya dengan lingkungan sekolah yang cukup.

Apabila dilihat hingga ke aspeknya, rata-rata skor tertinggi di antara ketiga aspek kesejahteraan siswa adalah aspek pemenuhan diri. Hal ini menunjukkan bahwa mayoritas partisipan melihat bahwa pemenuhan diri saat berada di sekolah merupakan hal yang paling penting dalam penilaian mereka terhadap diri sendiri dan hubungannya dengan sekolah.

\section{Saran}

Sampel SMAN asrama pada penelitian ini sebelumnya adalah sekolah negeri biasa (bukan asrama) dan baru satu tahun terbentuk sebagai sekolah asrama. Kondisi seperti ini diasumsikan memengaruhi absennya perbedaan antara SMAN asrama dengan yang bukan asrama untuk aspek hubungan sosial. Maka dari itu, untuk penelitian selanjutnya, tampaknya perlu menyertakan
SMAN asrama yang sudah terbentuk lama sebagai sekolah asrama sebagai sampel. Dengan demikian, peneliti bisa melihat perbedaan SMAN asrama dengan yang bukan asrama secara mendalam untuk aspek hubungan sosial.

Selain itu, mengingat kesejahteraan siswa penting bagi perkembangan siswa di sekolah dan juga kehidupannya secara menyeluruh, pemerintah perlu melakukan pengawasan terhadap sekolah-sekolah, baik sekolah dengan model asrama ataupun bukan, mulai dari kondisi sekolah, hubungan sekolah, serta pemenuhan diri siswa di sekolah. Pemenuhan diri siswa, melalui kegiatan-kegiatan seperti ekstrakurikuler yang beragam, program-program kesiswaan, dan lain sebagainya, perlu ditekankan, karena sama pentingnya dengan kegiatan akademis di sekolah.

\section{DAFTAR PUSTAKA}

\section{Jurnal}

Bronfenbrenner, U. (1970). Reaction to Social Pressure from Adults versus Peers Among Soviet Day School and Boarding School Pupils in the Perspective of an American Sample. Journal of Personality and Social Psychology, 15, 179-189.

Finn, P. J. (2012). Preparing for Power in Elite Boarding Schools Aid in Working-Class Schools. Theory into Practice, 51, 57-63.

Holden, M. J., Izzo, C., Nunno, M., Smith, E. G., Endres, T., Holden, J. C., \& Kuhn, F. (2010). Children and Residential Experiences: a Comprehensive Strategy for Implementing a Research-Informed Program Model for Residential Care. Child Welfare, 89, 131-149.

Konu, A., \& Rimpela, M. (2002). Well-Being in School: A Conceptual Model. Health Promotion International, 17(1), 79-87.

Martin, J. Andrew., Papworth, Brad., Ginns, Paul., Liem, Gregory Arief D. (2014). Boarding School, Academic Motivation and Engagement and Psychological Well Being: A Large-Scale Investigation. American Educational Research Journal, 51 (5), 1007-1049. 
Scott, D., \& Langhorne, A. (2012). Believing in Native Girls: Characteristics from Baseline Assessment. American Indian and Alaska Native Mental Health Research. The Journal of the National Center, 19, 15-36.

Sen Keung, N.P. (1999). Students Perception of Quality of School Life in Hong Kong Primary Schools. Educational Research Journal, 14 (1), 49-72.

\section{Buku}

Baron, Robert A., Byrne, Brascombe, Nyla R., Donn. (2008). Social Psychology (1 $\left.2^{\text {th }} \mathrm{ed}\right)$. USA: Pearson Education.

Beeby, CE. (1982). Pendidikan di Indonesia. Jakarta: Penilaian dan Pedoman Perencanaan LPSP3.

Bronfenbrenner, U. (1994). "Ecological Models oHuman Development." In M. Gauvain \& M. Cole (Eds.), International Encyclopedia of Education (2nd ed., Vol. 3, pp. 37-43). New York, NY: Freeman.

Bronfenbrenner, U. (2000). "Ecological Systems Theory." In A. E. Kazdin (Ed.), Encyclopedia of psychology, 3, 129-133, New York, NY: Oxford University Press.

Chase, S. A. (2008). Perfectly Prep: Gender Extremes at a New England Prep School. New York, NY: Oxford University Press.

Cookson, P. W. (2009). Perspectives on Elite Boarding Schools. In M. Berends, M. G. Springer, D. Ballou, \& H. J. Walberg (Eds.), Handbook of Research on School Choice (pp. 461-478). New York, NY: Routledge.

Cree, A. C. (2000). Lights Out and Be Quiet! A Sociological Research in Australian Boarding Education (2nd ed.). Parkville, Australia: Australasian Combined University Press.

Gaztambide-Ferna'ndez, R. A. (2009). The Best of The Best: Becoming Elite at an American Boarding School. Cambridge, MA: Harvard University Press.

Hurlock, Elizabeth B. (1980). Psikologi Perkembangan: Suatu Pendekatan Sepanjang Rentang Kehidupan Edisi Kelima. Editor: Ridwan Max Sijabat. Jakarta: Erlangga.

Khan, S. R. (2010). Privilege: The Making of An Adolescent Elite at St Paul's School. Princeton, NJ: Princeton University Press.
Kumar, Ranjit. (2011). Research Methodology. Australia: SAGE Publications.

Noble, T., McGrath, H., Roffey, S., \& Rowling, L. (2008). A Scoping Study On Student Wellbeing. Canberra: Department of Education, Employment \& Workplace Relations.

Papalia, Diane E., Feldman, Ruth Duskin., Martorell, Gabriela. (2015). Menyelami Perkembangan Manusia Edisi 12 Buku 2. Editor: M. Masykur dan Rahmawati. Jakarta: Salemba Humanika.

Ryan, Kevin., \& Cooper, James M. (1984). Those Who Can Teach. Ilnois: Houghton Millin.

Santrock, John W. (1998). Child Development ( $8^{\text {th }}$ ed). Boston: McGraw Hill

Shaughessy, J.J., Zechmeister, E.B., \& Zechmeister, J.S. (2000). Research Methods in Psychology. Boston: McGraw-Hill.

Shaver, K.G. (1981). Principles of Social Psychology. Cambridge : Winthrop.

The Association of Boarding Schools. (2003). Boarding Experience Outcomes: High School, Post-College, Mid-Career, and Late-Career Groups. Asheville, NC: Author.

\section{Skripsi dan Tesis}

Kurniasih, Nursita. dan Lestari, Sri. (2017). Kesejahteraan Siswa di Sekolah Berasrama. Thesis. Program Magister Sains Psikologi Sekolah Pascasarjana Universitas Muhammadiyah Surakarta.

Praningtyas, Dini. (2010). Hubungan Antara Bullying dan School Well Being Pada Siswa SMA Di Jakarta. Skripsi. Fakultas Psikologi Universitas Indonesia.

Williams, R. (2011). The Socialization of The Power Elite in an American Boarding School (Unpublished Senior Thesis). Haverford College, Haverford, PA.

Winurini, Sulis. (2004). Perbedaan Quality of School Life Pada Siswa Kelas 3 SMA Swasta Plus Dengan Siswa Kelas 3 SMA Negeri Plus. Skripsi. Fakultas Psikologi Universitas Indonesia.

\section{Internet}

Malang Sebagai Kota Pendidikan Sejak Masa Hindia Belanda. https://malang.merdeka.com/kabarmalang/malang-sebagai-kota-pendidikan-sejakmasa-hindia-belanda-160502n.html, diakses 28 September 2018. 
Program Unggulan SMAN 3 Malang. http://www. sman3-malang.sch.id/program-unggulan, diakses 28 September 2018.

\section{Lain-Lain}

SMAN 3 Malang. (tt). Buku Panduan Peserta Didik SMAN 3 Malang.

Pemerintah Provinsi Jawa Timur Dinas Pendidikan Sekolah Menengah Atas Negeri Taruna Nala Jawa Timur. (tt). Panduan PPDB SMA Negeri Taruna Nala Jawa Timur Tahun Pelajaran 2018/2019.

Leonard, Carl., Bourke, Sid., Schofield, Neville. (2000). Quality of School Life and Absenteeism in Primary Schools. Paper Presented at the AARE Annual Conference, 4-7 December 2000, Sidney. 